\title{
Presence of Reciprocal Synapses in the Rabbit Carotid Body
}

\author{
Shigeji Matsumoto, Takashi Uchida, Tamio Nakajima and Hidehiro Ozawa \\ First Department of Oral Surgery (Prof. N. Tokiwa) and First Department of Oral Anatomy \\ (Prof. H. Ozawa), Niigata University School of Dentistry, Niigata, Japan
}

Received May 7, 1980

\begin{abstract}
Summary. The synaptic junctions between glomus cells and nerve endings in the rabbit carotid body were studied by electron microscopy. Many of them were morphologically of afferent type, glomus cells being presynaptic to nerve endings; occurrence of eff erent synapses was less common than that of afferent synapses. In addition, reciprocal synapses in which two or more junctions of opposite polarity were lying side by side were frequently seen particularly between large nerve endings and glomus cells. Some single synapses were discovered to be part of reciprocal synapses through examination of serial sections. The results support possible participation of dopamine in a modulatory feedback loop through reciprocal synapses in the rabbit carotid body.
\end{abstract}

It has been suggested that glomus cells are receptors responsible for detection of gas tensions and subsequent generation of chemoreceptor nerve discharges by releasing a transmitter substance (Eyzaguirre, Nishi and Fidone, 1972; ZApata, StensaAs and Eyzaguirre, 1977). The assumption, however, was questioned, since dopamine, a possible transmitter in glomus cells, was shown to cause inhibition of chemoreceptor activity in the cat (Llados and Zapata, 1978; Docherty and McQueen, 1978). On the bases of their ultrastructural and electrophysiological studies, McDonaLD and Mitchell (1975) postulated that glomus cells are interneurons modulating the sensitivity of chemoreceptor nerve endings through reciprocal synapses which enable them to form inhibitory feedback loops between glomus cells and nerve endings. The current study was undertaken to see if the ultrastructure of the carotid body is consistent with our physiological findings which also indicated the modulatory role of dopamine in the rabbit (Matsumoto et al., 1980).

\section{MATERIALS AND METHODS}

Rabbits were anesthetized with intravenous sodium pentobarbital and ventilated artificially with room air. After the ascending aorta was perfused with $2.5 \%$ glutaraldehyde in $0.1 \mathrm{M}$ phosphate buffer ( $\mathrm{pH} 7.2-7.4$ ) for $10 \mathrm{~min}$, the carotid body tissues were excised, stored overnight in the same fixative, post-fixed with $1 \%$ osmium tetroxide in $0.1 \mathrm{M}$ phosphate buffer $(\mathrm{pH} 7.2-7.4)$, then dehydrated in acetone and 
embedded in Araldite. Ultrathin sections were made on a Sorvall ultramicrotome, stained with uranyl acetate and lead acetate viewed on a Hitachi HU-11DS electron microscope.

\section{RESULTS}

In the rabbit carotid body, three different types of synapses were recognized between glomus cells (type I cells) and nerve endings. Many of them were morphologically of afferent type in which glomus cells were presynaptic to nerve endings. They were characterized by either diffuse or cone-shaped densification of the presynaptic

a

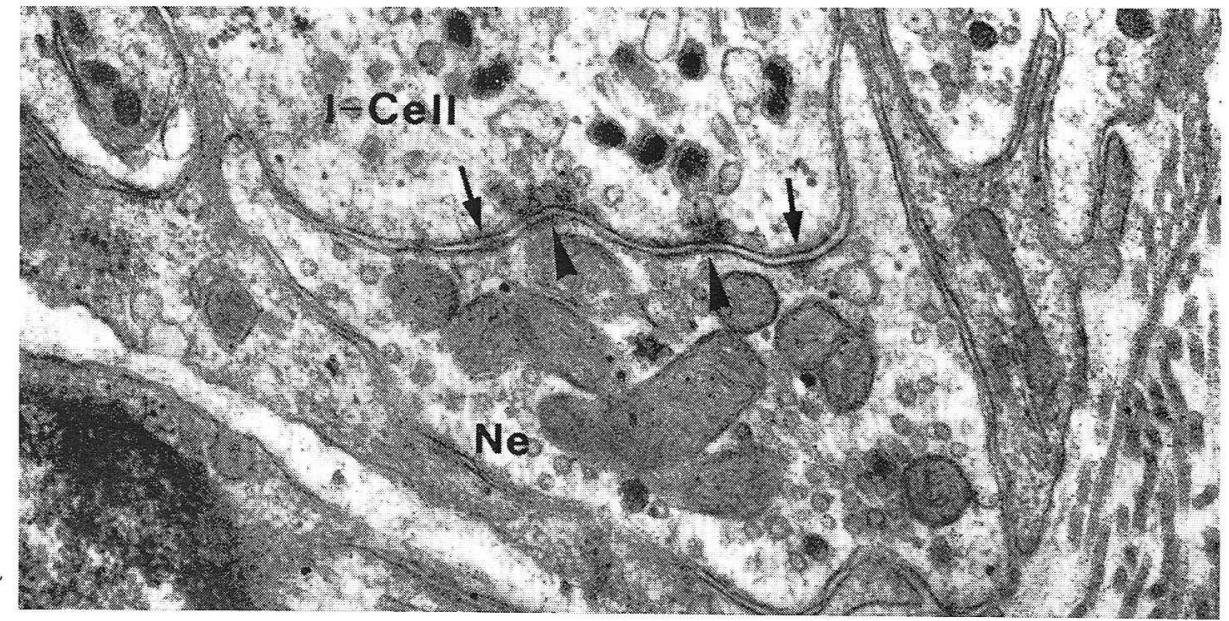

b

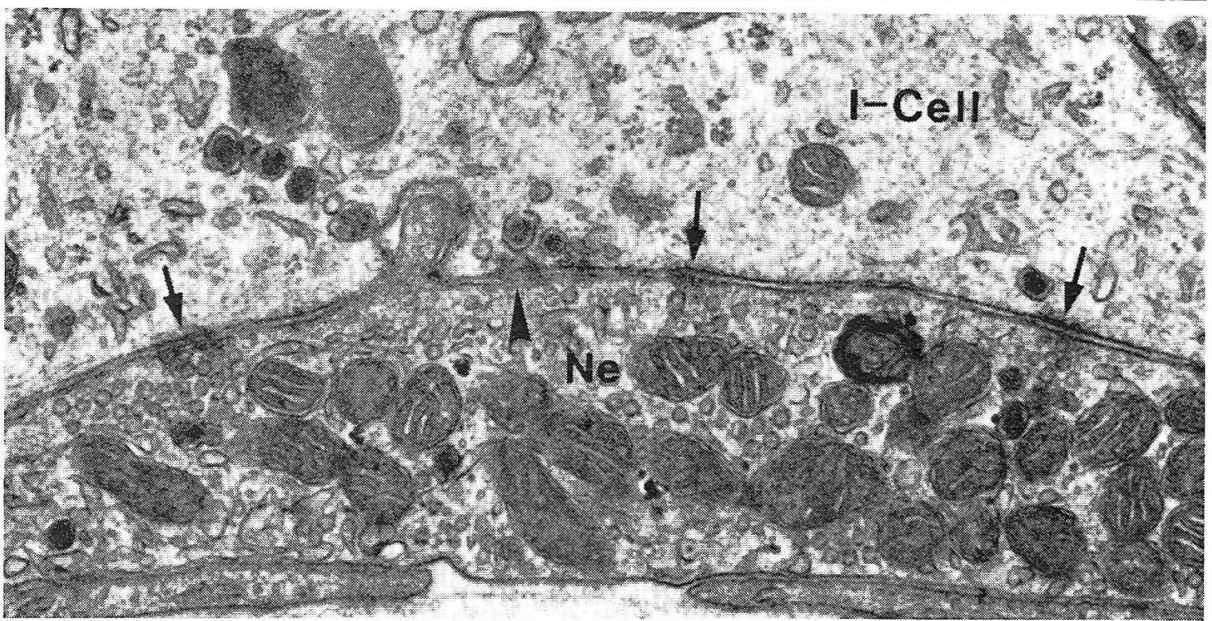

Fig. 1. Presence of reciprocal synapses between type I cell $(\mathrm{I}$-Cell $)$ and nerve ending $(\mathrm{Ne})$. In afferent components, accumulation of either clear vesicles (a) or dense-cored vesicles (b) was seen on cell side (arrowheads), whereas in the other components located close to afferent components, clear vesicles were seen in close apposition to thickened membrane of nerve ending (arrows). a: $\times 40,000 ; \mathrm{b}: \times 38,000$ 
membrane of glomus cells accompanied by accumulation of clear vesicles (40-60 nm) and/or dense-cored vesicles of varing sizes. The densification of the postsynaptic membrane was generally less conspicuous and there was no accumulation of synaptic vesicles on the neural side. Junctions with the morphological characteristics of the efferent synapse were also present, though their occurrence was less common than that of the afferent synapses. In most of the efferent type synapses, clear vesicles $(30-50 \mathrm{~nm})$ were aggregated close to the thickened membrane of nerve endings. The densification of the postsynaptic membrane was noted, but no vesicles were present on the glomus cell side. In addition, reciprocal synapses in which two or more junctions of opposite polarity were lying side by side were frequently seen particularly between large nerve endings and glomus cells. The basic structures of each component of the reciprocal synapse were indistinguishable from those of single synapses (Fig. 1). More importantly, afferent or efferent synapses which appeared to exist independently in a single section were often shown to have their counterpart efferent or afferent natures in another section obtained by serial sectioning (Fig. 2).

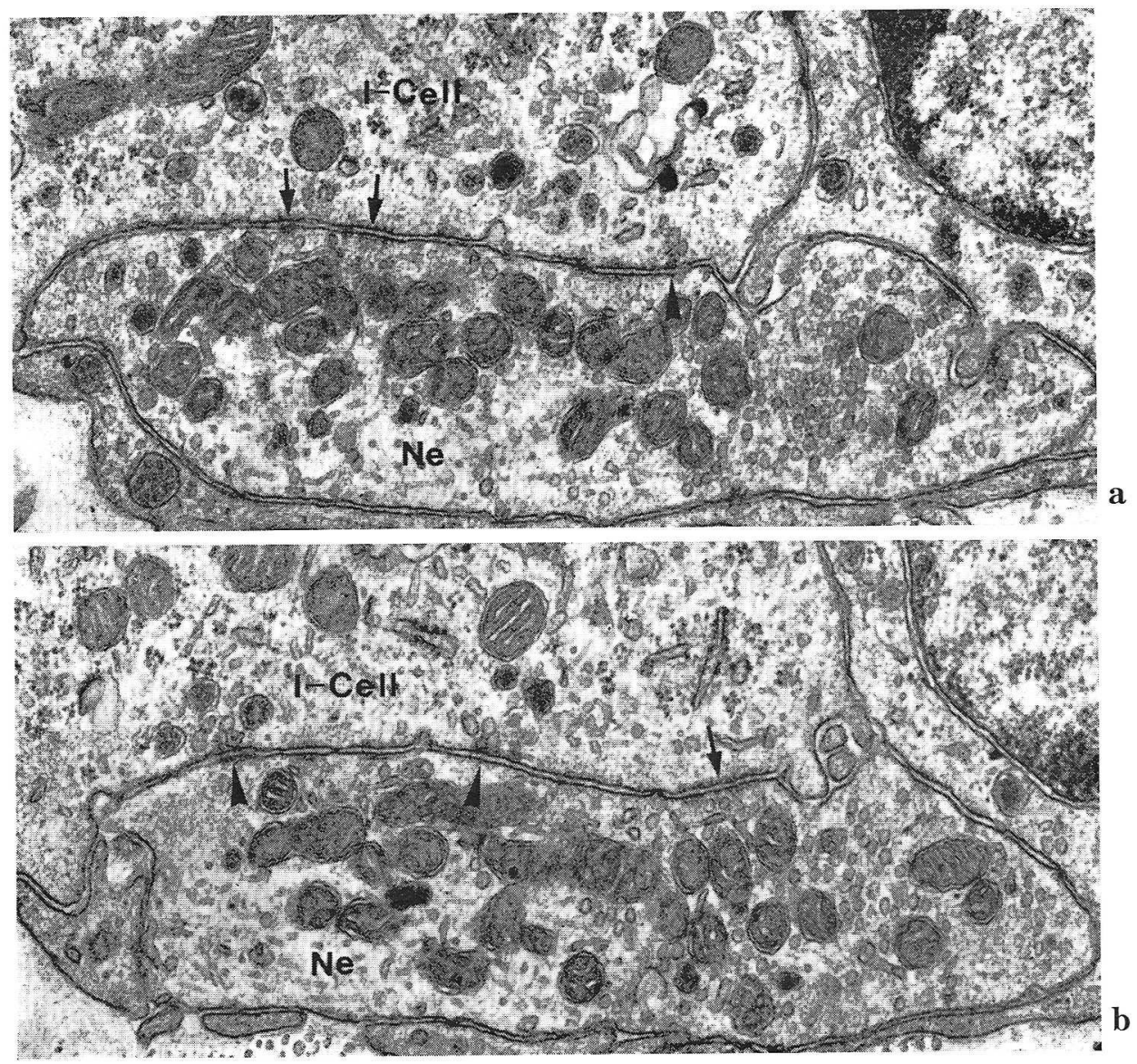

Fig. 2. Appearance of either afferent (arrowheads) or efferent (arrows) components of reciprocal synapses on type I cell ( $\mathrm{I}$-Cell) and nerve ending $(\mathrm{Ne})$ in serial sections. a, b: $\times 38,000$ 


\section{DISCUSSION}

Synaptic mechanism of the carotid body chemoreceptor has been a matter of controversy. Earlier electron microscopists demonstrated accumulations of synaptic vesicles only on the side of nerve terminals. Hence, Biscoe, Lall and Sampson (1970) stated that all the nerve terminals on the glomus cell of the cat carotid body are efferent. Kobayashi and Uehara (1970), however, found an afferent synaptic complex in the mouse carotid body and interpreted this synaptic complex to be the site of chemosensory transmission (see also Kовау аsнi, 1971).

Later McDonald and Mitchell (1975) reported that in the rat approximately $5 \%$ of afferent nerve endings were interconnected with glomus cells by reciprocal synapses. Since then, the presence of this type of synapse has been confirmed in many species and their functional role has been matter of dispute because the findings postulated the presence of efferent effects of nerve endings on glomus cells (OSBORNE and Butler, 1975; King et al., 1975; SMith and Mills, 1976). Interestingly, instead of increasing nerve discharges from the carotid body like acetylcholine, dopamine has a marked depressant effect on chemoreceptor nerve activity. Thus, OsBorne and BUtLer (1975) developed a model of a positive feedback loop in which, in hypoxic conditions, the release of dopamine from glomus cell is reduced, allowing an increase in spontaneous nerve discharges which, in turn, causes release of acetylcholine from nerve endings to reduce the rate of dopamine secretion, thus leading to further depolarization of nerve endings. McDonald and Mitchell (1975) proposed another interpretation stating that afferent nerve endings represent chemoreceptors and that their activity is controlled by glomus cells acting as interneurons through a negative feedback mechanism. The theory was based on the morphological similarities of glomus cells to neurons containing reciprocal synaptic contacts with afferent nerve endings and the input-output synaptic circuit from efferent to afferent nerves. According to Verna (1979), however, the occurrence of reciprocal synapses is quite exceptional in the rabbit carotid body. Furthermore, it is reported that dopamine may be excitatory in the animal (MonTi-Bloch and Eyzaguirre, 1977). Therefore, Verna (1979) stated that the modulatory feedback mechanism by dopamine does not work in this species.

In our previous experiments, the ventilatory effects of intracarotid dopamine through the chemoreceptor reflex in the rabbit were mainly inhibitions which were similar to those in the cat. This inhibitory effect was completely abolished after an intracarotid injection of haloperidol, a specific antagonist of dopamine, which led to prominent and sustained ventilatory excitation (Матsumoto et al., 1980). The haloperidol-induced excitation can not be explained without the tonic inhibition of chemoreceptor nerve activity by dopamine. In the current study, many reciprocal synapses were found to be present and some of the single synapses were shown to be components of reciprocal synapses in serial sections. The findings are in agreement with the indication that a published electron micrograph of the rabbit carotid body seems to have a reciprocal synapse (McDonald and Mitchell, 1975). Therefore, it seems to be quite conceivable that these reciprocal synapses are playing an essential role in the induction of the modulatory effect of dopamine which may constitute a part of a feedback loop. 


\title{
ウサギの頸動脈小体にみられる交叉性シナプスについて
}

\author{
松本茂二, 内田隆, 中島民雄, 小沢英浩
}

ウサギの頸動脈小体の主細胞と神経終末との間のシナプス結合を電子顕微鏡で調べた．そ れらの多くは，解剖学的に 主細胞側にシナプス小胞がみられる 求心性のタイプであった. 遠心性のシナプスは，求心性のものに比べて少なかった，加えて，二つまたは それ以上 の 逆の極性をもつシナプスが 互いに近接して存在する交叉性シナプスは，特に大きな神 経終末と主細胞との間でしばしばみられた。 また，連続切片で，単一のシナプスのある ものは，交文性シナプスの成分であることが判った。 ウサギの頸動脈小体でのドパミンに よる求心性神経活動の調節には, 交叉性シナプスを介したフィードバックループが関与し ているであろう。

\section{REFERENCES}

Docherty, R. J. and D. S. McQueen: Inhibitory action of dopamine on cat carotid chemoreceptors. J. Physiol. 279: 425-436 (1978).

Eyzaguirre, C., K. Nishi and S. Fidone: Chemoreceptor synapses in the carotid body. Fed. Proc. 31: 1385-1393 (1972).

King, A. S., D. Z. King, R. D. Hodges and J. Henry : Synaptic morpholgy of the carotid body of the domestic fowl. Cell Tiss. Res. 162: 459-473 (1975).

Kobayashi, S.: Comparative cytological studies of the carotid body. 2. Ultrastructure of the synapses on the chief cell. Arch. histol. jap. 33: 397-420 (1971).

Kobayashi, S. and M. Uehara : Occurrence of afferent synaptic complexes in the carotid body of the mouse. Arch. histol. jap. 32: 193-201 (1970).

Llados, F. and P. Zapata : Effects of dopamine analogues and antagonists on carotid body chemoreceptors in situ. J. Physiol. 274: 487-499 (1978).

Matsumoto, S., T. Nagao, A. Ibi and T. Nakajima: Effects of carotid body chemoreceptor stimulation by dopamine on ventilation. Arch. Int. Pharmacodyn. (1980, in press).

McDonald, D. M. and R. A. Mitchell : The innervation of glomus cells, ganglion cells and blood vessels in the rat carotid body: a quantitative ultrastructural analysis. J. Neurocytol. 4: 177230 (1975).

Monti-Bloch, L. and C. Eyzaguirre: Sited by A. Verna. Ultrastructure of the carotid body in the mammals. Int. Rev. Cytol. 60: 271-329 (1977).

Osborne, M. P. and P. J. Butler: New theory for receptor mechanism of carotid body chemoreceptors. Nature 254: 701-703 (1975).

Smith, P. G. and E. Mills: Autographic identification of the terminations of petrosal ganglion neurons in the carotid body. Brain Res. 113: 174-178 (1976).

Verna, A.: Ultrastructure of the carotid body in the mammals. Int. Rev. Cytol. 60: 271-329 (1979).

Zapata, P., L. J. Stensaas and C. Eyzaguirre: Recovery of chemosensory function of regenerating carotid nerve fibers. In: (ed. by) H. Acker, S. Fidone, D. Pallot, C. Eyzaguirre, D. W. Lübbers and R. W. Torrance: Chemoreception in the carotid body. Springer-Verlag, Berlin, 1977 (p. 44-50).

松本茂二

T951 新潟市学校町 2

新潟大学歯学部

口腔外科第一教室
Dr. Shigeji Matsumoto

First Department of Oral Surgery

Niigata University School of Dentistry

2-5274 Gakkocho, Niigata

951 Japan 